\title{
ANALISIS TINGKAT KEBAKUAN BAHASA INDONESIA PADA ARTIKEL GALAMEDIA DITINJAU DARI ASPEK KALIMAT EFEKTIF SERTA PEMANFAATANNYA SEBAGAI BAHAN AJAR BAHASA INDONESIA PADA SISWA KELAS VII
}

\author{
Syifa Nuraini Latifah \\ Guru SMK 5 Bandung \\ Email: syifanurainilatifah@gmail.com
}

\begin{abstract}
ABSTRAK
Penelitian ini dilatarbelakangi minimnya kemampuan siswa dalam memahami dan menggunakan kalimat efektif. Rumusan masalah dalam penelitian ini yaitu:1) Bagaimana tingkat kebakuan bahasa Indonesia pada artikel pendidikan dalam koran Galamedia ditinjau dari aspek kalimat efektif? 2) Bagaimana bentuk kesalahan pemakaian kalimat bahasa Indonesia pada artikel pendidikan dalam koran Galamedia ditinjau dari aspek kalimat efektif? 3) Bagaimana pemanfaatan hasil analisis tingkat kebakuan pemakaian bahasa Indonesia pada artikel pendidikan dalam koran Galamedia ditinjau dari aspek kalimat efektif sebagai bahan ajar bahasa Indonesia. Penelitian ini menggunakan metode kualitatif deskriptif. Dari proses di atas diperoleh data, bahwa setelah dilakukannya analisis pada kebakuan kalimat dan kesalahan kalimat dalam artikel Galamedia, kemudian dijadikan bahan ajar, siswa mampu menentukan kalimat efektif dan tidak efektif. Keberhasilan dapat dilihat dari hasil 10 siswa yang mampu menjawab instrumen yang penulis ujicobakan. Bahan ajar berbentuk modul tersebut sudah valid karena telah divalidasi berdasarkan pertimbangan kriteria pemilihan bahan ajar yang baik. Bahan ajar modul hasil analisis dari artikel Galamedia dapat dijadikan salah satu upaya untuk meningkatkan kemampuan menggunakan kalimat efektif pada siswa kelas VII.
\end{abstract}

Kata-kata kunci:artikel Galamedia, kalimat efektif, dan bahan ajar.

\section{ABSTRACT}

This research is backgrounded lack of students' abilities in understanding and using language effectively. The problems of this research are:1) What is standard educative level of Indonesian newspaper article in terms of aspects Galamedia effective sentence? 2) What is sort of usage errors educative Indonesian sentences on newspaper articles Galamedia in terms of aspects of effective sentence? 3) How to use the results of the analysis of the level of usage standard educative Indonesian newspaper article in terms of aspects sentence Galamedia effective as teaching Indonesian materials. This research uses qualitative descriptive method. From the above data showed that after doing an analysis on standard sentences and syntax errors in the article Galamedia, then used as teaching materials, students are able to determine the effective and ineffective sentence. The success can be seen from the results of 10 students who were able to answer instruments that the author tested. Instructional materials form the module is valid because it has been validated by consideration of criteria for selecting a good teaching materials. Teaching materials module of articles Galamedia analysis results can be used as one of the efforts to improve the ability to use language effectively in class VII.

Key words:articles Galamedia, effective sentence, and teaching materials. 


\section{PENDAHULUAN}

Bahasa Indonesia merupakan bahasa yang terpenting di negara kita. Pentingnya peranan bahasa Indonesia antara lain bersumber pada ikrar ketiga Sumpah Pemuda 1928 dan pasal 36 UUD 1945. Di samping itu, ada beberapa alasan lain yang ikut mengangkat derajatnya. Hal ini akan dilihat dari jumlah penutur, luas penyebaran, dan peranannya sebagai sarana ilmu, susastra, dan ungkapan budaya lain yang dianggap bernilai (Muslich, 2010:1).

Chaer dan Leonie (2010:190) mengungkapkan, bahwa kebijaksanaan bahasa dapat memilih dan menentukan sebuah bahasa dari sejumlah bahasa yang ada dalam suatu negara untuk dijadikan bahasa nasional atau bahasa resmi kenegaraan dari negara tersebut. Kemudian perencanaan bahasa dapat memilih dan menentukan sebuah ragam bahasa dari ragam-ragam yang ada pada bahasa yang sudah dipilih untuk menjadi ragam baku atau ragam standar bahasa tersebut.

Lebih lanjut dikatakan oleh Chaer dan Leonie (2010:191), berbicara tentang bahasa baku dan bahasa nonbaku, berarti kita membicarakan tentang variasi bahasa, karena yang disebut bahasa baku itu adalah salah satu variasi bahasa (dari sekian banyak variasi) yang diangkat dan disepakati sebagai ragam bahasa yang akan dijadikan tolok ukur sebagai bahasa yang "baik dan benar" dalam komunikasi yang bersifat resmi, baik secara lisan maupun tulisan.

Salah satu variasi bahasa yang akrab digunakan masyarakat adalah variasi bahasa yang digunakan dalam surat kabar. Sebagai media penyampai informasi, bahasa dalam surat kabar harus variatif dan enak dibaca. Menurut Sarwoko (2007:4), bahasa yang digunakan media massa bersandar kepada bahasa baku, tetapi pemakaian bahasa baku di media massa memang berbeda. Struktur kalimat lebih longgar, tidak normatif, pilihan katanya pun lebih bebas, tanpa beban perihal kebakuannya.

Salah satu ragam bahasa baku tulis yang sering dijumpai dalam kehidupan sehari-hari adalah pada artikel. Dalam Kamus Besar Bahasa Indonesia (1995:57), pengertian artikel adalah karya tulis lengkap di majalah, surat kabar, dan sebagainya. Kebakuan bahasa yang digunakan akan mempengaruhi kualitas sebuah berita yang disajikan dalam artikel. Menurut Anggarani, dkk. (2006:1), penulisan kalimat yang digunakan dalam bahasa tulis harus berupa ragam tulis ba$\mathrm{ku}$. Kalimat ragam tulis baku hendaknya berupa kalimat efektif, yaitu kalimat yang memenuhi kriteria jelas, sesuai dengan kaidah, dan enak dibaca. Menurut Kurniawan (2012:46), kalimat efektif adalah kalimat yang mengungkapkan gagasan penulisnya sedemikian rupa, sehingga pembaca memahami gagasan yang sama.

Pada kenyataannya, masih banyak artikel di media massa yang belum memenuhi standar kebakuan bahasa Indonesia akibat norma bahasa Indonesia yang sudah bersifat majemuk. Alwi, dkk. (1988:12) menjelaskan, bahwa dewasa ini ada dua perangkat norma bahasa yang bertumpang tindih. Yang satu berupa norma yang dikodifikasi dalam bentuk buku tata bahasa sekolah dan yang diajarkan kepada para siswanya. Yang lain ialah norma berdasarkan adat pemakaian (usage) yang belum dimodifikasi secara resmi yang antara lain dipakai oleh kalangan media massa.

\section{KAJIAN TEORETIS}

Penggunaan bahasa pada media massa, tak sedikit membawa pengaruh pula pada pembacanya. Kesalahan pemakaian bahasa di media massa biasanya diikuti oleh masyarakat yang kurang memperhatikan kebakuan bahasa. Pada akhirnya kesalahan tersebut dianggap 
hal biasa dan lebih banyak digunakan dalam kehidupan sehari-hari. Kesalahan yang terdapat pada artikel dalam surat kabar salah satunya pada struktur kalimat. Menurut Sarwoko (2007:8), masyarakat mencontoh penggunaan kalimat dari media massa yang agak kurang bertanggungjawab. Dengan begitu banyak sekali orang yang membuat kalimat tanpa subjek, memulai kalimat dengan kata depan, terbawanya struktur bahasa lisan dalam bahasa tulis.

Kenyataan di lapangan, masih banyak siswa yang belum mampu memahami tata bahasa baku bahasa Indonesia, terutama pada aspek kalimat. Penelitian mengenai kesalahan berbahasa pada siswa kelas VII banyak dilakukan. salah satunya yang dipaparkan oleh Muliasari (2015) dalam situs karyailmiah.um.ac.id/index.php/sastra-indonesia/article/view/33538 yang diakses pada tanggal 22 Juni 2016. Dalam teks laporan hasil observasi siswa kelas VII SMPN 3 Malang terdapat lima jenis kesalahan pengembangan kalimat yaitu:

(1) penggunaan kalimat tidak lengkap;

(2) penggunaan kalimat tidak logis; (3) penggunaan kalimat tidak efektif; (4) penggunaan kalimat rancu; dan (5) penggunaan kalimat ambigu.

Berdasarkan Kurikulum 2013 edisi revisi tahun 2016 tingkat SMP/MTS, pada mata pelajaran Bahasa Indonesia kelas VII terdapat beberapa jenis teks yang akan dipelajari oleh siswa antara lain teks laporan hasil deskripsi, teks cerita fantasi, teks prosedur, teks laporan hasil observasi, puisi rakyat, teks fabel, surat, dan buku fiksi dan nonfiksi. Dari kedelapan jenis teks tersebut, unsur kebahasaan yang harus dikuasai oleh siswa cukup kompleks. Beberapa aspek kebahasaan yang terdapat dalam buku teks siswa contohnya afiksasi, kata baku dan tidak baku, konjungsi, dan kalimat majemuk. Salah satu aspek kebahasaan yang penting dikuasai oleh siswa adalah penguasaan terhadap pemakaian kalimat efektif.

Pateda mengemukakan (1989:31), bahwa guru yang mengajarkan suatu bahasa sering menemukan kesalahan yang dibuat si terdidik. Kesalahan yang berhubungan dengan linguistik misalnya fonologi, morfologi, atau sintaksis. Telah banyak usaha untuk mengatasi temuan-temuan guru itu yang sebenarnya bertujuan agar proses belajar mengajar berhasil dengan baik. Penggunaan bahan ajar yang tepat akan meningkatkan pemahaman siswa mengenai kompetensi yang harus dicapai.

\section{METODOLOGI PENELITIAN}

Penelitian ini akan menggunakan penelitian kualitatif deskriptif. Jenis penelitian kualitatif deskriptif adalah jenis penelitian yang akan peneliti gunakan dalam menganalisis tingkat kebakuan bahasa Indonesia pada artikel Galamedia ditinjau dari aspek kalimat efektif serta pemanfaatannya sebagai bahan ajar bahasa Indonesia siswa kelas VII.

Menurut Mahmud (2012:89), penelitian kualitatif merupakan suatu pendekatan dalam melakukan penelitian yang berorientasi pada fenomena atau gejala yang bersifat alami. Penelitian kualitatif bersifat mendeskripsikan 'makna data' atau fenomena yang dapat ditangkap oleh peneliti, dengan menunjukkan bukti-buktinya. Penelitian ini menggunakan metode deskriptif. Suwandi \& Basrowi (2008:28) menjelaskan pula, bahwa pada metode deskripsi, data yang dikumpulkan berupa kata-kata, gambar, dan bukan angka-angka. Semua yang dikumpulkan berkemungkinan menjadi kunci terhadap apa yang sudah diteliti.

Sumber data utama dalam penelitian ini adalah adalah kata-kata, kalimat, pernyataan, ungkapan pada artikel pendidikan dalam koran Galamedia edisi Agustus-Desember 2016. Enam artikel 
dipilih oleh penulis untuk dianalisis kebakuannya. Teknik pengumpulan data penelitian ini menggunakan teknik observasi deskriptif, teknik studi pustaka, teknik studi dokumentasi, dan teknik angket (kuesioner).

Sampel yang digunakan pada penelitian ini adalah siswa MTs. Ar-Rosyidiyah kelas VII yang berjumlah sepuluh orang. Hasil analisis terhadap kebakuan kalimat pada artikel kemudian dijadikan bahan ajar dan diujicobakan kepada sepuluh orang siswa.

Dalam penelitian kualitatif, peneliti merupakan alat (instrumen) pengumpul data utama. Berkaitan dengan itu, dalam penelitian ini penulis menyusun instrumen penelitian. Instrumen penelitian dibuat dalam bentuk format tabel yang berisi data-data penelitian yang telah diklasifikasikan berdasarkan kategori kebakuan pemakaian kalimat efektif dan bentuk kesalahan pemakain kalimat efektif. Format tabel disusun dari mulai nomor, kode, bentuk kebakuan, bentuk kesalahan dan bentuk benar. Selain itu, setiap data diberikan kode khusus untuk memudahkan analisis.

\section{HASIL PENELITIAN DAN PEMBAHASAN}

Deskripsi data berfungsi menjabarkan hasil analisis tingkat kebakuan bahasa Indonesia pada artikel Galamedia ditinjau dari aspek kalimat efektif. Data hasil penelitian diperoleh dari sampel sepuluh orang siswa kelas VII serta kuesioner yang ditujukkan kepada beberapa guru.

Penulis mengujicobakan keefektifan modul kepada guru MTs. yang berjumlah 3 orang. Sebelum penulis mengujicobakan modul, penulis menyusun lembar penilaian modul berupa angket (kuesioner). Kuesioner berisi beberapa aspek yang harus dinilai berdasarkan kriteria bahan ajar yang baik. Kriteria yang dinilai dari modul tersebut menca- kup aspek tuntutan kurikulum, tuntutan bahasa, dan tuntutan psikologis.

Angket/kuesioner tersebut diberikan kepada masing-masing tiga orang guru dan diisi sesuai dengan penilaian terhadap bahan ajar modul. Angket tersebut diberikan bertujuan untuk mengetahui apakah modul sudah memenuhi kriteria penyusunan bahan ajar atau bahkan sebaliknya. Berikut akan disampaikan hasil ujicoba modul berupa penilaian isi modul kepada guru bahasa Indonesia.

\section{Hasil Uji Coba kepada Guru (data terlampir)}

1) Guru pertama

Guru pertama adalah seorang guru MTs. Ar-Rosyidiyah bernama Ibu Yeti Nurhayati, S.Pd. Beliau adalah guru bahasa dan Sastra Indonesia yang bertugas mengajar siswa kelas IX. Pengalaman kerjanya sudah 14 tahun. Kriteria penilaian modul berdasarkan tuntutan kurikulum, aspek bahasa, dan aspek psikologi. Berdasakan hasil penilaian terhadap keefektifan modul, guru pertama memberikan nilai 5 untuk semua indikator aspek yang dicantumkan penulis pada aspek tuntutan kurikulum. Dapat disimpulkan, bahwa modul sudah sangat sesuai dengan tuntutan kurikulum karena diberikan penilaian sangat baik oleh guru.

Aspek selanjutnya yang dinilai oleh guru pertama adalah aspek bahasa. Beliau memberikan nilai 5 untuk aspek indikator tata bahasa Indonesia, kalimat efektif dan ejaan, sedangkan untuk indikator aspek mengenai bahasa komunikatif dan keterpahaman bahasa, beliau memberikan nilai masing-masing 4. Dapat disimpulkan bahwa modul sudah baik dalam pemakaian bahasa dan sudah sangat baik dalam pemakaian kalimat.

Aspek terakhir yang dinilai oleh guru adalah aspek psikologis. Aspek psikologis ini disesuaikan dengan tahap 
perkembangan siswa sesuai dengan usianya. Guru memberikan nilai masing-masing 4 untuk setiap indikator aspek pada aspek psikologis.

Dapat disimpulkan, bahwa modul sudah baik dalam mempertimbangkan aspek psikologis siswa SMP/MTS kelas VII.

\section{2) Guru Kedua}

Guru kedua adalah seorang guru MTsN 2 Bandung bernama Bapak Gunawan Widodo, S. Pd., M. M.Pd. Beliau adalah guru bahasa dan Sastra Indonesia yang bertugas mengajar siswa kelas VIII dan kelas IX. Pengalaman kerjanya sudah 17 tahun. Kriteria penilaian modul berdasarkan tuntutan kurikulum, aspek bahasa, dan aspek psikologi. Berdasakan hasil penilaian terhadap keefektifan modul, guru kedua memberikan nilai 5 untuk semua indikator aspek yang dicantumkan penulis pada aspek tuntutan kurikulum. Dapat disimpulkan, bahwa modul sudah sangat sesuai dengan tuntutan kurikulum karena diberikan penilaian sangat baik oleh guru.

Aspek selanjutnya yang dinilai oleh guru adalah aspek bahasa. Beliau memberikan nilai 5 untuk aspek indikator tata bahasa Indonesia, kalimat efektif dan Ejaan, sedangkan untuk indikator aspek mengenai bahasa komunikatif dan keterpahaman bahasa, guru kedua memberikan nilai masing-masing 4. Dapat disimpulkan bahwa modul sudah baik dalam pemakaian bahasa dan sudah sangat baik dalam pemakaian kalimat.

Aspek terakhir yang dinilai oleh guru adalah aspek psikologis. Aspek psikologis ini disesuaikan dengan tahap perkembangan siswa sesuai dengan usianya. Guru memberikan nilai 5 pada aspek taraf intelegensi siswa dan motivasi siswa. Untuk aspek ketertarikan minat siswa, guru kedua memberikan nilai 4 .

Dapat disimpulkan, bahwa modul sudah sangat baik dalam mempertim- bangkan aspek psikologis siswa SMP/MTS kelas VII.

\section{3) Guru Ketiga}

Guru ketiga adalah seorang guru MTsN 2 Bandung bernama Ibu Rohaeti, S.Pd. Beliau adalah guru bahasa dan Sastra Indonesia yang bertugas mengajar siswa kelas VII. Pengalaman kerjanya sudah 18 tahun. Kriteria penilaian modul berdasarkan tuntutan kurikulum, aspek bahasa, dan aspek psikologi. Berdasakan hasil penilaian terhadap keefektifan modul, guru ketiga memberikan nilai 5 untuk semua indikator aspek yang dicantumkan penulis pada aspek tuntutan kurikulum. Dapat disimpulkan, bahwa modul sudah sangat sesuai dengan tuntutan kurikulum karena diberikan penilaian sangat baik oleh guru.

Aspek selanjutnya yang dinilai oleh guru ketiga adalah aspek bahasa. Beliau memberikan nilai 4 untuk semua aspek indikator pada aspek bahasa. Aspek bahasa menyangkut penggunaan bahasa dan penggunaan kalimat. Dapat disimpulkan bahwa modul sudah baik dalam pemakaian bahasa.

Aspek terakhir yang dinilai oleh guru ketiga adalah aspek psikologis. Aspek psikologis ini disesuaikan dengan tahap perkembangan siswa sesuai dengan usianya. Beliau memberikan nilai 4 pada semua aspek indikator pada aspek psikologis.

Dapat disimpulkan, bahwa modul sudah baik dalam mempertimbangkan aspek psikologis siswa SMP/MTS kelas VII.

\section{Hasil Uji Coba kepada Siswa (data terlampir) \\ 1) Hasil Uji Coba Siswa Pertama}

Siswa pertama bernama Artvina Suci Lestari. Dia adalah siswa MTs. ArRosyidiyah kelas VII A. Berdasarkan jawaban pada lembar kerja siswa dalam modul kalimat efektif, siswa sudah mampu menjawab ketiga soal yang pe- 
nulis ajukan. Siswa mampu menjawab soal No. 1 mengenai kalimat efektif. Siswa sudah mampu menentukan kalimat yang memenuhi kesepadanan struktur dan ketegasan makna. Sementara untuk soal No. 2 mengenai kalimat tidak efektif, siswa sudah mampu menentukan kalimat yang mengandung keborosan kata di dalamnya. Kalimat tidak efektif lain yang mampu ditemukan oleh siswa adalah kesalahan penempatan konjungsi. Siswa juga mampu menjawab soal No. 3 mengenai perbedaan kalimat efektif dan tidak efektif. Dapat disimpulkan bahwa siswa sudah mampu membedakan kalimat yang sudah efektif dan tidak efektif.

\section{2) Hasil Uji Coba Siswa Kedua}

Siswa pertama bernama Aji Anggara. Dia adalah siswa MTs. Ar-Rosyidiyah kelas VII A. Berdasarkan jawaban pada lembar kerja siswa dalam modul kalimat efektif, siswa sudah mampu menjawab ketiga soal yang penulis ajukan. Siswa mampu menjawab soal No. 1 mengenai kalimat efektif. Siswa sudah mampu menentukan kalimat yang memenuhi syarat penekanan, kesepadanan struktur dan keparalelan. Sementara untuk soal No. 2 mengenai kalimat tidak efektif, siswa sudah mampu menentukan kalimat yang tidak memiliki unsur inti kalimat dan kalimat yang mengandung kontaminasi di dalamnya. Kalimat tidak efektif lain yang mampu ditemukan oleh siswa adalah kesalahan penempatan konjungsi. Siswa juga mampu menjawab soal No. 3 mengenai perbedaan kalimat efektif dan tidak efektif. Dapat disim-pulkan bahwa siswa sudah mampu membedakan kalimat yang sudah efektif dan tidak efektif.

\section{3) Hasil Uji Coba Siswa Ketiga}

Siswa ketiga bernama Faisal Akbar. Dia adalah siswa MTs. Ar-Rosyidiyah kelas VII A. Berdasarkan jawaban pada lembar kerja siswa dalam modul kalimat efektif, siswa sudah mampu menjawab ketiga soal yang penulis ajukan. Siswa mampu menjawab soal No. 1 mengenai kalimat efektif. Siswa sudah mampu menentukan kalimat yang sudah memenuhi kesepadanan struktur dan kevariasian. Sementara untuk soal No. 2 mengenai kalimat tidak efektif, siswa sudah mampu menentukan kalimat yang mengandung ketidaksepadanan struktur dan ketidaktepatan penemapatan konjungsi dalam kalimat. Kalimat tidak efektif lain yang sudah mampu ditemukan oleh siswa adalah kesalahan penempatan konjungsi. Siswa juga mampu menjawab soal No. 3 mengenai perbedaan kalimat efektif dan tidak efektif. Dapat disimpulkan bahwa siswa sudah mampu membedakan kalimat yang sudah efektif dan tidak efektif.

\section{4) Hasil Uji Coba Siswa Keempat}

Siswa keempat bernama Vera Rustika. Dia adalah siswa MTs. Ar-Rosyidiyah kelas VII A. Berdasarkan jawaban pada lembar kerja siswa dalam modul kalimat efektif, siswa sudah mampu menjawab ketiga soal yang penulis ajukan. Siswa mampu menjawab soal No. 1 mengenai kalimat efektif. Siswa sudah mampu menentukan kalimat yang memenuhi kesepadanan struktur dan kevariasian. Sementara untuk soal No. 2 mengenai kalimat tidak efektif, siswa sudah mampu menentukan kalimat yang tidak hemat. Kalimat tidak efektif lain yang mampu ditemukan oleh siswa adalah ketidakjelasan unsur inti kalimat. Kalimat tidak efektif selanjutnya yang mampu ditemukan oleh siswa adalah kalimat yang mengandung keambiguan makna. Siswa juga mampu menjawab soal No. 3 mengenai perbedaan kalimat efektif dan tidak efektif. Dapat disimpulkan bahwa siswa sudah mampu membedakan kalimat yang sudah efektif dan tidak efektif.

\section{5) Hasil Uji Coba Siswa Kelima}

Siswa kelima bernama Widia Karlina. Dia adalah siswa MTs. Ar-Rosyidiyah kelas VII A. Berdasarkan jawaban 
pada lembar kerja siswa dalam modul kalimat efektif, siswa sudah mampu menjawab ketiga soal yang penulis ajukan. Siswa mampu menjawab soal No. 1 mengenai kalimat efektif. Siswa sudah mampu menentukan kalimat yang memenuhi kesepadanan struktur dan keparalelan bentuk. Sementara untuk soal No. 2 mengenai kalimat tidak efektif, siswa sudah mampu menentukan kalimat yang mengandung keborosan kata di dalamnya. Kalimat tidak efektif lain yang mampu ditemukan oleh siswa adalah ketidakjelasan unsur inti kalimat. Kalimat tidak efektif selanjutnya yang mampu ditemukan oleh siswa adalah kalimat yang mengandung keambiguan makna. Siswa juga mampu menjawab soal No. 3 mengenai perbedaan kalimat efektif dan tidak efektif. Dapat disimpulkan bahwa siswa sudah mampu membedakan kalimat yang sudah efektif dan tidak efektif.

\section{6) Hasil Uji Coba Siswa Keenam}

Siswa keenam bernama Putri Wulandari. Dia adalah siswa MTs. ArRosyidiyah kelas VII A. Berdasarkan jawaban pada lembar kerja siswa dalam modul kalimat efektif, siswa sudah mampu menjawab ketiga soal yang penulis ajukan. Siswa mampu menjawab soal No. 1 mengenai kalimat efektif. Siswa sudah mampu menentukan kalimat yang memenuhi kesepadanan struktur dan keparalelan bentuk. Sementara untuk soal No. 2 mengenai kalimat tidak efektif, siswa sudah mampu menentukan kalimat yang tidak memiliki kejelasan unsur inti kalimat. Kalimat tidak efektif lain yang mampu ditemukan oleh siswa adalah kalimat yang tidak hemat karena subjeknya diulang dua kali. Kalimat tidak efektif lainnya yang ditemukan oleh siswa adalah kalimat yang di dalamnya mengandung keambiguan makna. Siswa juga mampu menjawab soal No. 3 mengenai perbedaan kalimat efektif dan tidak efektif. Dapat disimpulkan bahwa siswa sudah mampu membedakan kalimat yang sudah efektif dan tidak efektif.

\section{7) Hasil Uji Coba Siswa Ketujuh}

Siswa ketujuh bernama Sarah Agustina Fahri Yanti. Dia adalah siswa MTs. Ar-Rosyidiyah kelas VII A. Berdasarkan jawaban pada lembar kerja siswa dalam modul kalimat efektif, siswa sudah mampu menjawab ketiga soal yang penulis ajukan. Siswa mampu menjawab soal No. 1 mengenai kalimat efektif. Siswa sudah mampu menentukan kalimat yang memenuhi kesepadanan struktur. Sementara untuk soal No. 2 mengenai kalimat tidak efektif, siswa sudah mampu menentukan kalimat yang mengandung keambiguan makna di dalamnya. Siswa juga mampu menjawab soal No. 3 mengenai perbedaan kalimat efektif dan tidak efektif. Dapat disimpulkan bahwa siswa cukup mampu membedakan kalimat yang sudah efektif dan tidak efektif.

\section{8) Hasil Uji Coba Siswa Kedelapan}

Siswa kedelapan bernama Suci Indah Pratiwi. Dia adalah siswa MTs. ArRosyidiyah kelas VII A. Berdasarkan jawaban pada lembar kerja siswa dalam modul kalimat efektif, siswa sudah mampu menjawab ketiga soal yang penulis ajukan. Siswa mampu menjawab soal No. 1 mengenai kalimat efektif. Siswa sudah mampu menentukan kalimat yang memenuhi ketegasan makna. Sementara untuk soal No. 2 mengenai kalimat tidak efektif, siswa sudah mampu menentukan kalimat yang mengandung kesalahan nalar di dalamnya. Siswa juga mampu menjawab soal No. 3 mengenai perbedaan kalimat efektif dan tidak efektif. Dapat disimpulkan bahwa siswa cukup mampu membedakan kalimat yang sudah efektif dan tidak efektif.

9) Hasil Uji Coba Siswa Kesembilan

Siswa kesembilan bernama Nabila Asy-Syifa. Dia adalah siswa MTs. ArRosyidiyah kelas VII A. Berdasarkan ja- 
waban pada lembar kerja siswa dalam modul kalimat efektif, siswa sudah mampu menjawab ketiga soal yang penulis ajukan. Siswa mampu menjawab soal No. 1 mengenai kalimat efektif. Siswa sudah mampu menentukan kalimat yang memenuhi syarat kevariasian dan penekanan. Kalimat efektif lainnya yang sudah mampu ditentukan siswa yaitu kalimat yang sudah memenuhi keparalelan bentuk. Sementara untuk soal No. 2 mengenai kalimat tidak efektif, siswa sudah mampu menentukan kalimat yang mengandung keborosan kata di dalamnya. Kalimat tidak efektif lain yang mampu ditemukan oleh siswa adalah kalimat yang tidak memiliki unsur inti. Siswa juga mampu menjawab soal No. 3 mengenai perbedaan kalimat efektif dan tidak efektif. Dapat disimpulkan bahwa siswa sudah mampu membedakan kalimat yang sudah efektif dan tidak efektif.

\section{0) Hasil Uji Coba Siswa Kesepuluh}

Siswa kesepuluh bernama Bebi Adinda Putri. Dia adalah siswa MTs. Ar-Rosyidiyah kelas VII A. Berdasarkan jawaban pada lembar kerja siswa dalam modul kalimat efektif, siswa sudah mampu menjawab ketiga soal yang penulis ajukan. Siswa mampu menjawab soal No. 1 mengenai kalimat efektif. Siswa sudah mampu menentukan kalimat yang memenuhi keparalelan bentuk dan kevariasian. Sementara untuk soal No. 2 mengenai kalimat tidak efektif, siswa sudah mampu menentukan kalimat yang tidak memiliki unsur inti kalimat. Kalimat tidak efektif lain yang mampu ditemukan oleh siswa adalah kalimat yang mengandung keambiguan. Siswa juga mampu menjawab soal No. 3 mengenai perbedaan kalimat efektif dan tidak efektif. Dapat disimpulkan bahwa siswa sudah mampu membedakan kalimat yang sudah efektif dan tidak efektif.

\section{SIMPULAN}

Dari hasil pengumpulan data, pendeskripsian dan pembahasan hasil penelitian mengenai Analisis Tingkat Kebakuan Bahasa Indonesia pada Artikel Galamedia Ditinjau dari aspek Kalimat Efektif serta Pemanfaatannya sebagai Bahan Ajar Bahasa Indonesia Siswa kelas VII, penulis dapat menarik kesimpulan sebagai berikut.

1. Berdasarkan hasil analisis penulis terhadap tingkat kebakuan bahasa Indonesia pada artikel Galamedia ditinjau dari aspek kalimat efektif, penulis menemukan kebakuan kalimat yang sudah terpenuhi sesuai dengan syarat-syarat keefektifan kalimat. Sampel yang penulis gunakan pada penelitian adalah enam buah artikel pendidikan pada koran Galamedia. Tingkat kebakuan bahasa Indonesia yang dianalisis pada penelitian ini adalah kebakuan kalimat ditinjau dari aspek kalimat efektif. Keefektifan kalimat memiliki syarat-syarat yaitu kesepadanan struktur, kevariasian, keparalelan, penekanan dan ketegasan makna. Syarat kalimat efektif yang sudah terpenuhi pada enam artikel yang dianalisis penulis sudah mencakup keseluruhan syarat kalimat efektif yang penulis kemukakan. Syarat keefektifan yang banyak ditemukan pada artikel adalah kesepadanan struktur. Dengan kata lain, artikel pendidikan dalam koran Galamedia secara garis besar sudah baku dalam pemakaian kalimatnya.

2. Berdasarkan hasil analisis penulis terhadap bentuk kesalahan yang ditemukan pada artikel pendidikan dalam koran Galamedia, penulis menemukan masih terdapat kalimat yang mengandung kesalahan dan tidak memenuhi syarat kebakuan kalimat. Kesalahan kalimat dilihat dari faktor-faktor penyebab ketidak- 
efektifan kalimat berupa kontaminasi atau kerancuan, ambiguitas atau keambiguan, ketidakjelasan subjek, kemubaziran preposisi dan ketidaktepatan bentuk dan makna kata. Dari enam buah artikel, masih terdapat beberapa kesalahan yang ditemukan dan menyebabkan kalimat menjadi tidak efektif. Kesalahan pemakaian kalimat yang ditemukan pada tiap artikel sebagian besar disebabkan oleh keambiguan makna dan ketidaktepatan unsur inti kalimat.

3. Hasil analisis terhadap kebakuan kalimat pada artikel Galamedia dan bentuk kesalahan yang ditemukan dijadikan sebuah bahan ajar berbentuk modul. Sebelum menyusun bahan ajar modul, penulis mempertimbangkan terlebih dahulu kriteria pemilihan bahan ajar yang baik untuk siswa SMP/MTS sesuai dengan tuntutan kurikulum, aspek bahasa dan aspek psikologis. Modul berisi petunjuk belajar, kompetensi inti, kompetensi dasar, indikator, tujuan pembelajaran, lembar kerja siswa dan kunci jawaban. Modul divalidasi terlebih dahulu oleh validator dan dinilai oleh guru sebelum diujicobakan kepada siswa. Hasil penilaian validator dan guru terhadap bahan ajar yang disusun penulis sudah sangat baik dari aspek tuntutan kurikulum karena keempat penilai memberikan poin terbesar yaitu 5 , juga sudah baik dari aspek bahasa dan psikologis karena keempat penilai memberikan poin 4. Berdasarkan jawaban siswa pada lembar kerja siswa, penulis simpulkan bahwa dengan bahan ajar berbentuk modul yang penulis berikan, siswa sudah mampu membedakan kalimat yang sudah efektif dan belum efektif. Hal tersebut dapat dilihat dari ketepatan sepuluh orang siswa yang mampu menentukan kalimat yang sudah me- menuhi syarat kesepadanan struktur, keparalelan, kevariasian, penekanan dan ketegasan makna. Begitu juga dengan kalimat yang belum efektif, mereka sudah mampu menentukannya berlandaskan teori mengenai faktor penyebab ketidakefektifan kalimat.

\section{DAFTAR PUSTAKA}

Alwi, dkk. (2008). Tata Bahasa Baku Bahasa Indonesia. Jakarta: Pusat Bahasa dan Balai Pustaka.

Anggarani, dkk. (2006). Mengasah Keterampilan Menulis Ilmiah di Perguruan Tinggi. Yogyakarta: Graha Ilmu.

Basrowi \& Suwandi (2008). Memahami Penelitian Kualitatif. Jakarta: Rineka Cipta.

Chaer, Abdul \& Leonie. (2010). Sosiolinguistik Perkenalan Awal. Jakarta: PT Rineka Cipta.

Kurniawan, Khaerudin. (2014). Bahasa Indonesia Keilmuan untuk Perguruan Tinggi. Bandung: UPI PRESS.

Mahmud. (2011). Metode Penelitian Pendidikan. Bandung:Pustaka Setia.

Muslich, Masnur. (2012). Garis-garis Besar Tata Bahasa Baku Bahasa Indonesia. Jakarta: Remaja Rosdakarya.

Muslich, Mansur. (2010). Bahasa Indonesia Pada Era Globalisasi. Jakarta: Remaja Rosdakarya.

Pateda, Mansoer. (1989). Analisis Kesalahan. NTT: Arnoldus.

Sarwoko, Adi. (2007). Inilah Bahasa Indonesia Jurnalistik. Yogyakarta: C.V Andi Offset.

Tim Departemen Pendidikan dan

Kebudayaan. (1995). Kamus Besar

Bahasa Indonesia. 